\title{
PEMANFAATAN DATA LANDSAT MULTITEMPORAL UNTUK PEMETAAN POLA EKSPANSI PERKOTAAN SECARA SPASIOTEMPORAL (STUDI KASUS PADA TIGA PERKOTAAN METROPOLITAN DI PULAU JAWA)
}

\author{
Like Indrawati ${ }^{1}$, Ari Cahyono ${ }^{2}$ \\ ${ }^{1}$ Program Studi Diploma 3 Penginderaan Jauh dan SIG, Departemen Teknologi Kebumian, \\ Sekolah Vokasi, UGM \\ Email: ${ }^{1}$ like.indrawati@ugm.ac.id \\ ${ }^{2}$ Departemen Sains Informasi Geografi, Fakultas Geografi, UGM \\ Email: ${ }^{2}$ aricahyono@ugm.ac.id
}

\begin{abstract}
Utilization of multitemporal remote sensing data among others can be used to determine the pattern of changes in urban expansion. One of the most important types of cities in urban systems is the metropolitan urban area that covers several districts and cities. This is because the region generally acts as the capital of the country, the provincial capital, and the center of economic activities that are national or strategic. Understanding urban expansion at different metropolitan urban levels is important for expanding knowledge in times of urban growth and its impact on the environment. Aims in this study are: (1) utilization of multitemporal Landsat data for mapping urban expansion patterns, (2) knowing the effectiveness of object-based classification for mapping of urban settlements and (3) spatiotemporal urban expansion pattern analysis in three metropolitan cities on Java Island.. In this study focused on three metropolitan urban in Java, namely DKI. Jakarta, Surabaya and Semarang. This study utilizing Landsat TM, ETM + and OLI image data to map urban settlement land cover using object-based classification with Random Forest algorithm. Next, quantifying the typology of urban expansion and compare the spatiotemporal pattern of urban expansion during 2005-2015 on the results of land cover mapping. This research has found that (1) object-based classification with Random Forest algorithm is quite effective in terms of time of work to map urban settlement cover on Landsat digital data having medium spatial resolution; (2) the three urban metropolia is experiencing rapid and massive development and has a very varied spatiotemporal pattern; (3) Size of the city affect the pattern of urban expansion, followed by rapid expansion of the region. Larger city size with relatively rapid expansion is more likely to experience the edge extension model, while smaller cities tend to develop with outlying models.
\end{abstract}

Keywords: Spatiotemporal pattern, urban expansion, urban expansion typhology quantification, object based image analysis 


\section{PENDAHULUAN}

Pesatnya pertumbuhan di wilayah perkotaan mendorong konversi penggunaan lahan dan menyebabkan dampak lingkungan dan ekologi yang besar. Dampak ini terjadi tidak hanya di wilayah perkotaan itu sendiri tetapi juga jauh melampaui batas-batas perkotaan terutama di kota-kota besar dan kota metropolitan di seluruh dunia termasuk di Indonesia. Bahkan, urbanisasi semakin menjadi faktor pendorong utama perubahan lanskap dan isu-isu lingkungan di skala yang lebih luas. Untuk lebih memahami bagaimana urbanisasi daerah mempengaruhi lingkungan, pola spasiotemporal ekspansi perkotaan dan kekuatan penggeraknya merupakan hal yang pertama diperhitungkan.

Ada empat jenis model ekspansi perkotaan, yaitu, lompatan (leapfrogging/ outlying), ekspansi tepi (edge-expansion), pengisian (infilling) dan memanjang (stripping), yang secara luas diakui untuk menggambarkan morfologi perkembangan perkotaan (Xu, et al, 2007). Secara khusus, lompatan (leapfrogging/ outlying) mengacu pada model di mana patch lahan baru tumbuh tidak berdekatan dengan patch lahan yang dikembangkan; ekspansi tepi (edge-expansion), merupakan pola di mana patch lahan baru tumbuh dipinggiran patch lahan yang ada; pengisian (infilling), mengacu pola di mana patch lahan baru berkembang di dalam patch lahan yang ada; dan memanjang (stripping) merupakan pola yang mana patch yang baru tumbuh di sepanjang jalan utama (Forman, et al, 1995).

Data penginderaan jauh telah digunakan secara luas untuk studi ekspansi perkotaan, data ini tersedia dengan resolusi spasial yang rinci serta frekuensi temporal yang memadai untuk morfologi perkotaan dan perubahannya. Terutama, informasi tentang sejarah perkembangan kota dapat diungkapkan oleh data penginderaan jauh multitemporal yang mana hal ini penting untuk mengukur proses pembangunan perkotaan. Di antara berbagai data penginderaan jauh yang tersedia, citra Landsat termasuk MSS, TM / ETM + dan OLI, merupakan salah satu data yang paling banyak digunakan untuk mengkaji ekspansi perkotaan (Schneider, et al, 2014). Mengintegrasikan data penginderaan jauh dengan lanskap analisis perkotaan sangat berguna untuk memahami pola spasiotemporal ekspansi perkotaan ( $\mathrm{Wu}$, et al, 2011).

Analisis citra berbasis objek (Object Based Image Analysis (OBIA)) merupakan salah satu metode mengekstraksi objek pada citra digital penginderaan jauh yang cukup efisien dan rinci (Blaschke, 2010; Puissant, 2014). Salah satu algoritma yang sering digunakan untuk pengklasifikasinya adalah random forest. Random Forest adalah sebuah algoritma machine learning yang diusulkan oleh Breiman (2001) untuk regresi dan klasifikasi. Metode teracu ini telah digunakan dalam berbagai bidang diantaranya dalam bidang genetika (Diaz-Uriarte and Alvarez deAndres, 2006), pencitraan medis (Genuer et al., 2010), atau ekologi (Cutler et al, 2007). Lebih spesifik dalam penginderaan jauh metode ini telah diterapkan untuk pemetaan tanah longsor (Stumpf Kerle, 2011), perkotaan (Guo et al., 2011), dan lahan pertanian (Duro eta al., 2012).

Salah satu tipe kota yang sangat penting dalam sistem perkotaan adalah kawasan perkotaan metropolitan yang wilayahnya mencakup beberapa daerah kabupaten dan kota. Hal ini dikarenakan kawasan tersebut umumnya berperan sebagai ibukota negara, ibu kota propinsi, dan pusat kegiatan ekonomi yang sifatnya nasional atau strategis.

Indonesia merupakan negara dengan pertumbuhan ekonomi yang cukup pesat di kawasan Asia Tenggara. Seiring dengan pertumbuhannya yang semakin pesat itu, melahirkan perkembangan dan pertumbuhan kota-kota besar di Indonesia menjadi kota metropolitan, diantaranya adalah Jakarta, Surabaya dan Semarang. Dalam beberapa hal, dapat dilihat secara langsung, kota-kota metropolitan ini, tumbuh dan berkembang dengan tidak terkendali. Hal ini menjadikan isu-isu utama pembangunan perkotaan di Indonesia secara umum terfokus pada masalah-masalah tertentu. Antara lain keterbatasan sarana/prasarana, merosotnya kualitas lingkungan, lemahnya penegakan pemanfaatan ruang, meningkatnya beberapa masalah sosial, serta tingginya kerentanan kota-kota di Indonesia terhadap bencana alam dan perubahan iklim. Penanganan terhadap isu-isu pembangunan perkotaan di Indonesia memerlukan upaya yang sangat luas. Penanganan tidak akan cukup, apabila ditangani melalui program pembangunan perkotaan yang bersifat fisik dan berorientasi ekonomi. Sudah saatnya arah pembangunan perkotaan di Indonesia diwujudkan melalui penguatan visi lingkungan, visi sosial serta perumusan misi-misi yang terencana dan terukur (www.bappenas.go.id, 2009). Oleh karena itu, mengambil perkotaan metropolitan sebagai contoh, memahami ekspansi perkotaan di skala regional 
yang mencakup kota-kota berbagai ukuran, penting untuk memperluas pengetahuan saat pertumbuhan perkotaan dapat menyebabkan dampak terhadap lingkungan dan ekologi.

Tujuan dalam penelitian ini adalah (1) pemanfaatan data Landsat multitemporal untuk pemetaan pola ekspansi perkotaan, (2) mengetahui efektivitas klasifikasi berbasis objek untuk pemetaan permukiman kota dan (3) analisis pola ekspansi perkotaan secara spasiotemporal pada tiga kota metropolitan di Pulau Jawa.

\section{Tinjauan Pustaka}

Mengembangkan metode kuantitatif untuk mengidentifikasi berbagai jenis ekspansi perkotaan berguna dan bermakna untuk membantu perencanaan penggunaan lahan baik pada skala lokal, regional dan Negara, hal ini akan lebih memahami dan mengatasi masalah yang berkaitan dengan urban sprawl. Dalam banyak penelitian sebelumnya, analisis pertumbuhan perkotaan dilakukan baik di skala metropolitan secara keseluruhan (Serra et al, 2003;. Xian dan Crane, 2005; Huang et al, 2007.). Teknologi tentang kuantifikasi jenis ekspansi kota yang berbeda dari data penginderaan jauh selama ini belum diteliti secara memadai.

Hoffhine Wilson et al. (2003) yang pertama melakukan kuantifikasi tiga jenis pertumbuhan perkotaan yaitu infilling, ekspansi tepi (edge-expansion), dan outlaying dari klasifikasi citra Landsat. Setiap jenis merupakan pola pertumbuhan khusus suatu perkotaan. Pengisian (infilling) berarti daerah non-urban dikelilingi oleh kota yang dikonversi ke perkotaan. Ekspansi tepi (edge-expansion) mengacu pada daerah perkotaan yang baru dikembangkan menyebar dari pinggiran patch perkotaan yang ada. Pertumbuhan outlaying cenderung didistribusikan pada jarak yang lebih besar dari daerah perkembangan yang ada. Hal ini dapat diklasifikasikan lebih lanjut menjadi pertumbuhan terisolasi, linear dan berkerumun (cluster).

Penginderaan jauh menyediakan cakupan spasial yang konsisten untuk daerah yang luas dengan detail spasial tinggi dan frekuensi temporal yang tinggi. Ini memiliki kelebihan dalam menggambarkan tren spasial temporal pertumbuhan perkotaan menggunakan citra multi-stage (Weng, 2002; Serra et al, 2003; Xian dan Crane, 2005; Huang et al, 2007). Dikombinasikan dengan metrik spasial, data penginderaan jauh menawarkan potensi untuk mengkarakterisasi perubahan dinamika pertumbuhan kota (Herold et al., 2003).

\section{Landasan Teori}

\section{Tipologi Ekspansi Perkotaan}

Antara ekspansi perkotaan dan urban sprawl sering ditempatkan pada istilah yang sama. Pertama karena sulit untuk membuat terjemahan istilah yang tepat dari bahasa Inggris ke bahasa lain, dan kedua, karena lebih pada fenomena yang terjadi saat ini dan urban sprawl telah menjadi bintang yang merongrong "otoritas" dari konsep yang lebih tua dari ekspansi perkotaan (Stan. 2013).

Pada dasarnya, ada tiga jenis utama dari pertumbuhan perkotaan yang didokumentasikan, yaitu: infilling, ekspansi tepi (edge-expansion) dan pertumbuhan spontan (Berling-Wolff dan $\mathrm{Wu}$ 2004a). Infilling berarti daerah non-perkotaan dikelilingi oleh perkotaan yang akan dikonversi menjadi perkotaan; ekspansi tepi (edge-expansion), juga disebut pembangunan pinggiran kota, mengacu pada daerah perkotaan yang baru dikembangkan menyebar dari pinggiran patch perkotaan yang ada; dan pertumbuhan spontan berarti patch perkotaan baru terbentuk dan tidak memiliki hubungan spasial langsung dengan patch perkotaan yang ada. Forman (1995) menyebutnya sebagai jenis proses lanskap 'perforasi', dan mendefinisikannya sebagai " proses pembuatan lubang di objek seperti habitat atau jenis lahan. " Jenis lain dari pertumbuhan perkotaan dapat dilihat sebagai beberapa kombinasi dari ketiga jenis. Atribut geometris serta distribusi spasial bervariasi antara yang berbeda pertumbuhan, jenis, dan yang lebih penting, arah dan kecepatan pembangunan mungkin berbeda. Studi tentang tipologi pertumbuhan perkotaan sangat berarti bagi teori perkotaan dan pemodelan (Luck dan $\mathrm{Wu}$ 2002). 


\section{Penginderaan Jauh untuk Kajian Ekspansi Perkotaan}

Penginderaan jauh telah menjadi alat yang tak terelakkan untuk inventarisasi sumber daya alam dan pemantauan lingkungan pada skala lokal, regional dan global selama tiga puluh tahun terakhir. Hal ini telah menjadi bagian integral dari teknologi informasi dan memberikan solusi untuk memfasilitasi pembangunan berkelanjutan sumber daya alam dan pelestarian lingkungan hidup. Aplikasi penelitian yang berorientasi di banyak negara telah menyebabkan penggunaan operasional dan komersial teknologi ini di berbagai bidang. Sejumlah penelitian yang dilakukan dengan menggunakan berbagai metodologi dan algoritma untuk menurunkan tutupan lahan dan mengubah informasi dari set data penginderaan jauh yang berbeda (Tateishi dan Kajiwara, 1991; Lichtenegger, 1992; Muchoney dan Haack, 1994; Lambin, 1996; Sailer et al ., 1997).

Data digital citra satelit, memungkinkan untuk secara akurat menghitung berbagai kategori tutupan lahan/ penggunaan lahan dan membantu dalam menjaga infrastruktur data spasial yang sangat penting untuk memantau ekspansi perkotaan dan studi deteksi perubahan (Lo, 1981, Mukherjee, 1987 dan Quarmby dan Cushine, 1989).

Pertumbuhan perkotaan bukanlah fenomena yang terisolasi. Kota dan kota-kota satelit disekitarnya dipengaruhi dan tergantung satu sama lain. Misalnya, pertumbuhan sebuah mega-city dapat mendorong atau menghambat perkembangan kota yang berdekatan. Aneksasi dan penggabungan antara kota membentuk kota kelompok atau siklus kota. Satelit penginderaan jauh resolusi menengah dapat digunakan untuk perencanaan kota regional. Saat data citra satelit dengan resolusi spasial menengah akan terus memainkan peran penting

\section{BAHAN DAN METODE PENELITIAN}

\section{Daerah Kajian}

Daerah penelitian yang dipilih berdasarkan pada tiga kota besar di Indonesia yang masuk dalam kategori kota metropolitan, yaitu DKI. Jakarta (Kawasan Metropolitan Jabodetabek), Semarang (Kawasan Metropolitan Kedungsepur) dan Surabaya (Kawasan Metropolitan Gerbang Kerto Susilo). Ketiga kota besar tersebut merupakan perkotaan metropolitan, yaitu wilayah metropolitan DKI Jakarta yang disebut Kawasan Jabodetabek yang terdiri dari DKI.Jakarta, Kota Bogor, Kabupaten Bogor, Kota Depok, Kabupaten Tangerang, Kota Tangerang, Kabupaten Tangerang Selatan, Kabupaten Bekasi dan Kota Bekasi. Wilayah metropolitan Semarang yang disebut dengan Kawasan Kedungsepur, yaitu Kabupaten Kendal, Kota Salatiga, Kota Semarang, Kabupaten Semarang, Kabupaten Grobogan, dan Kabupaten Demak. Wilayah metropolitan Surabaya yang disebut dengan Kawasan Gerbang Kerto Susilo yang terdiri dari Kabupaten Gresik, Kabupaten Bangkalan, Kabupaten Mojokerto, Kota Surabaya, Kabupaten Sidoarjo, dan Kabupaten Lamongan. Adapun batas penelitian yang digunakan bukan merupakan batas administrasi, akan tetapi batas area persegi yang meliputi wilayah kota metropolitan tersebut. Perbandingan letak geografis dan sosial ekonomi daerah penelitian dapat dilihat pada tabel 1 berikut ini.

Tabel 1. Letak geografis dan sosial ekonomi daerah penelitian

\begin{tabular}{l|lll}
\hline & DKI. Jakarta & Semarang & Surabaya \\
\hline Letak Geografis & $106^{\circ} 22^{\prime}-106^{\circ} 58^{\prime}(\mathrm{BT})$ & $109^{\circ} 35^{\prime}-110^{\circ} 50^{\prime}(\mathrm{BT})$ & $112^{\circ} 36^{\prime}-112^{\circ} 54^{\prime}(\mathrm{BT})$ \\
& $5^{\circ} 19^{\prime}-6^{\circ} 23^{\prime}(\mathrm{LS})$ & $6^{\circ} 50^{\prime}-7^{\circ} 10^{\prime}(\mathrm{LS})$ & $7^{\circ} 9^{\prime}-7^{\circ} 21^{\prime}(\mathrm{LS})$ \\
Luas Wilayah $\left(\mathrm{Km}^{2)}\right.$ & 661,52 & 373,70 & 333,063 \\
Populasi (juta) & 10,08 & 1,78 & 2,8 \\
PRDB (triliun) & $1.395,5$ & 134,3 & 305,31 \\
\hline
\end{tabular}

Sumber: Statistik Daerah DKI Jakarta tahun 2015, Semarang Dalam Angka (2015), Surabaya Dalam Angka (2015) 


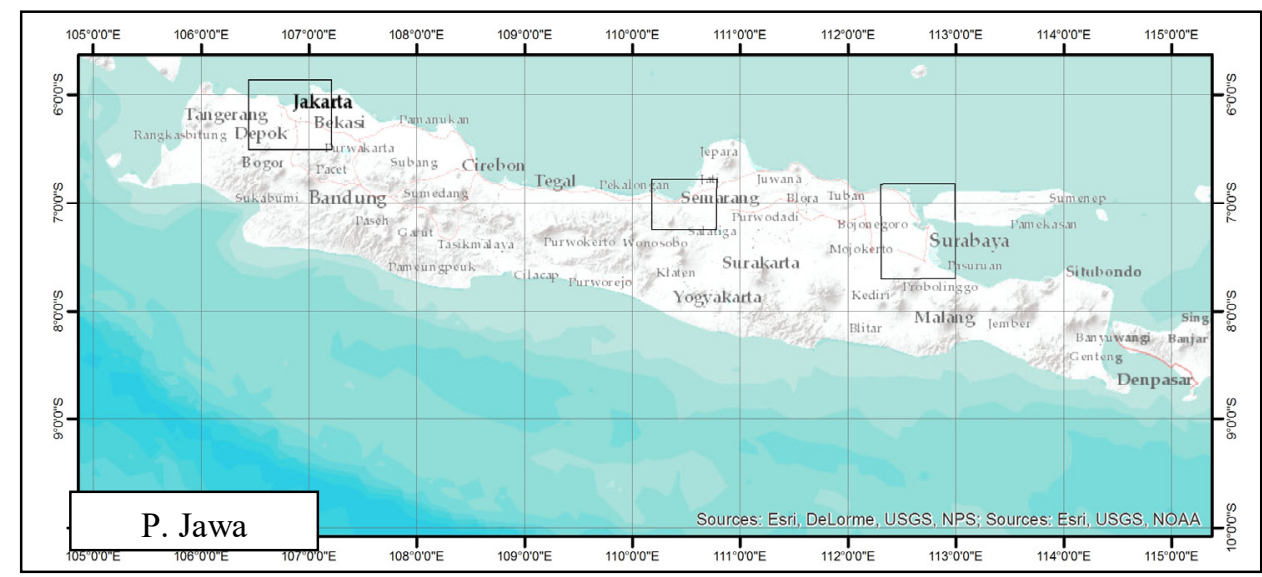

Gambar 1. Lokasi Penelitian

\section{Data Penginderaan Jauh}

Bahan yang digunakan dalam penelitian ini adalah citra Landsat 7 ETM+ (tahun 2005) serta Landsat 8 OLI ( tahun 2015) yang diperoleh dengan cara mengunduh secara gratis melalui web https://earthexplorer.usgs.gov/ pada bulan Juni 2017 dan Peta Dasar (Single Base Map) BIG.

Tabel 2. Data Citra yang digunakan

\begin{tabular}{|c|c|c|c|c|c|c|}
\hline \multirow[t]{2}{*}{ Tahun } & \multicolumn{2}{|c|}{ DKI Jakarta } & \multicolumn{2}{|c|}{ Semarang } & \multicolumn{2}{|c|}{ Surabaya } \\
\hline & Path/Row & Tanggal & Path/Row & Tanggal & Path/Row & Tanggal \\
\hline 2005 & $122 / 064$ & 2005.07 .10 & $120 / 065$ & 2005.08 .29 & $118 / 065$ & 2005.09 .16 \\
\hline 2015 & $122 / 064$ & 2015.08 .31 & $120 / 065$ & 2015.09 .18 & $118 / 065$ & 2015.09 .20 \\
\hline
\end{tabular}

Sumber: https://lv.eosda.com

\section{Tahap Pra-Pemrosesan Citra}

Tahap ini adalah tahap koreksi radiometrik dan koreksi geometrik. Koreksi geometrik terutama dilakukan antar citra multitemporal pada masing-masing area of interest penelitian. Koreksi geometrik dilakukan dengan metode image to image antara citra multitemporal.

\section{Tahap Pemrosesan Citra}

a. Pembuatan Peta Penutup Lahan:

Pola spasiotemporal ekspansi perkotaan dikuantifikasi berdasarkan peta penutup lahan tahun 2005 dan tahun 2015. Klasifikasi penutup lahan yang digunakan berdasarkan pada klasifikasi SNI 7645:2010 (Klasifikasi Penutup Lahan Skala 1 : 250.000). Klasifikasi berasal dari citra Landsat $(\mathrm{ETM}+$ dan OLI) dengan resolusi spasial 30 meter, menggunakan pendekatan klasifikasi berbasis obyek.

Langkah pertama yang dilakukan adalah membuat peta penutup lahan tahun 2015 menggunakan metode analisis citra berbasis objek. Peta penutup lahan tahun 2015 kemudian digunakan sebagai peta referensi untuk menghasilkan peta penutup lahan tahun 2005. Selain itu, editing manual ekstensif dilakukan untuk memperbaiki klasifikasi secara visual dengan menggunakan referensi citra resolusi spasial tinggi dari citra Google Earth dan Google Street View.

Tahap pemrosesan citra ini meliputi beberapa tahap yaitu:

Tahap segmentasi dan komputasi atribut objek

Segmentasi menggunakan algoritma multiresolution segmentation (MSR) pada saluran biru, hijau, merah, inframerah dekat, inframerah tengah 1 dan inframerah tengah 2. Parameter yang optimal (shape, compactness, smoothness). Metode teracu divalidasi menggunakan poligon referensi yang dipilih secara acak. 


\section{Tahap Klasifikasi}

Tahap klasifikasi, menggunakan metode Random Forest (RF) classifier (Breiman, 2001). Klasifikasi $R F$ telah banyak digunakan untuk klasifikasi karena kekuatan prediksinya dan karena memungkinkan memperhitungkan fitur-fitur penting yang digunakan untuk mengklasifikasikan obyek sasaran, yang dikenal sebagai variabel penting (Corcoran et al., 2013; Guo et al, 2011; Stumpf dan Kerle, 2011). Atribut yang digunakan dalam klasifikasi ini mencakup informasi spektral (nilai rata-rata), informasi geometrik (bentuk dan ukuran metrik) dan parameter tekstur.

\section{Kuantifikasi Tipologi Ekspansi Perkotaan}

Berdasarkan peta permukiman perkotaan, dalam penelitian ini mengidentifikasi perkembangan lahan baru pada periode, 2005-2015. Hal ini dilakukan dengan analisis overlay menggunakan peta permukiman perkotaan selama kurun waktu 10 tahun. Klasifikasi perkembangan lahan baru terdiri dari empat model-ekspansi perkotaan yaitu lompatan spasial (leapfrogging/ Outlying), ekspansi-tepi (edge-expansion), pengisian (infilling) dan memanjang (Stripping) dengan mengikuti metode rinci dalam Xu et al. (2007) dan Li et al. (2013). Secara khusus, persamaan di bawah ini digunakan untuk mengklasifikasikan patch perkembangan lahan baru:

$$
R i=p c / p i
$$

Dimana, $R i$ adalah rasio untuk patch i yang baru berkembang, $p c$ adalah batas bersama antara patch perkembangan baru dan patch perkembangan sebelumnya, dan $p i$ adalah perimeter total patch i. Nilai $\mathrm{R}$ berkisar antara 0 dan 1. Aturan heuristik sederhana diterapkan untuk mengkategorikan patch ke dalam empat tipologi ekspansi perkotaan yaitu: Jika $R i>0,5$, maka Patch $\mathrm{i}==$ infill; jika $R i<=0,5$, maka Patch $\mathrm{i}==$ edge-expansion; jika $R i==0$ dan Patch i tidak berdekatan dengan jalan utama, maka Patch i =e outlying; dan jika $R i==0$ dan Patch i bersebelahan dengan jalan utama, maka Patch $\mathrm{i}==$ strip. Bila nilai $\mathrm{R}$ lebih dari 50\%, sebagian besar patch yang baru dikembangkan dikelilingi oleh patch perkotaan yang ada, dan oleh karena itu dianggap sebagai pengembangan infill.

Kuatifikasi tipologi ekspansi perkotaan ini menggunakan kode yang dijalankan dengan Phyton pada software ArcGis 10.2. Data spasial yang diperlukan dalam penghitungan ini adalah peta permukiman perkotaan tahun 2005 dan tahun 2015, serta peta jaringan jalan. Proses kuantifikasi ini cukup memakan waktu, karena penghitungan dilakukan pada tiap-tiap patch (poligon) permukiman baru, semakin banyak patch baru maka semakin lama proses perhitungannya. Pada penelitian ini patch baru yang dihasilkan pada kota metropolitan DKI. Jakarta sebanyak 5.082 patch, kota metropolitan Semarang sebanyak 318 patch dan kota metropolitan Surabaya sebanyak 1.264 patch.

Analisis

Untuk mengukur besarnya ekspansi perkotaan pada masing-masing kota metropolitan digunakan rumus perhitungan sebagai berikut:

$$
\begin{aligned}
& A I=\underline{A}_{\text {end }}-A_{\text {start }} \\
& d \\
& A G R(\%)=100 \% \times\left[\left(A_{\text {end }} / A_{\text {start }}\right)^{1 / d}-1\right] \\
& P_{\text {model }}=\left(A_{\text {model }} / A_{\text {new }}\right) \times 100 \%
\end{aligned}
$$

Dimana $A I\left(\mathrm{~km}^{2} /\right.$ tahun) dan $A G R(\%)$ adalah masing-masing pertumbuhan tahunan dan tingkat pertumbuhan tahunan lahan perkotaan, $A_{\text {end }}$ dan $A_{\text {start }}$ adalah luas wilayah perkotaan masingmasing pada periode awal dan akhir, dan $d$ adalah rentang waktu studi selama waktu tertentu. Secara khusus, dihitung luas lahan yang baru (Persamaan (4), $A_{\text {new }}$ ) untuk mengukur besarnya ekspansi perkotaan. Untuk morfologi ekspansi, dengan cara menghitung persentase luas total (Persamaan (4), $\left.P_{\text {model }}\right)$ dan distribusi ukuran patch untuk masing-masing model ekspansi $\left(A_{\text {model }}\right)$ $(\mathrm{Yu}, 2017)$. Pertumbuhan tahunan ini secara langsung mengukur perubahan tahunan daerah perkotaan, sementara tingkat pertumbuhan tahunan menghilangkan ukuran efek kota dan lebih 
sesuai untuk perbandingan perluasan kota untuk kota yang berbeda pada periode yang sama $(\mathrm{Wu}$, et al, 2015).

\section{HASIL DAN PEMBAHASAN}

\section{Peta Permukiman Perkotaan}

Peta permukiman perkotaan di daerah penelitian menggunakan analisis citra berbasis objek dengan klasifikasi $R F$ (Random Forest). $R F$ sebagai "alat" klasifikasi baru dan telah banyak digunakan di bidang klasifikasi data penginderaan jauh karena kinerjanya yang sangat baik (Ma et al,2015, Stumpf, et al, 2011, Puissant et al, 2014, Lei Ma et al, 2017).

Pada metode klasifikasi ini, objek berukuran besar/ luas dengan warna dan tekstur yang seragam akan terklasifikasikan dengan baik, sedangkan objek yang berukuran kecil dan kompleks dalam hal warna dan tekstur cenderung sulit untuk terklasifikasi dengan baik (Indrawati, 2016). Pada tahap segmentasi objek permukiman, pemisahan objek permukiman kota dengan objek yang lain dapat dengan mudah terpisahkan. Hal ini karena objek permukiman kota relatif homogen, kriteria homogenitas yang juga bersinonim dengan heterogenitas minimum ini seringkali dapat meningkatkan kualitas ekstraksi objek, terutama dalam hal kriteria warna (Parsa, dkk, 2015). Sebaliknya pada permukiman yang berada semakin diluar perkotaan, sering ditemukan permukiman berasosiasi dengan vegetasi sehingga warna menjadi heterogen, hal ini menyebabkan ekstraksi objek menjadi menurun. Seringnya pantulan atap genteng keramik yang hampir sama dengan tanah terbuka kering juga menyebabkan kesalahan dalam ekstraksi objek, terlebih apabila citra direkam pada musim kemarau. Akan tetapi pada pemetaan permukiman perkotaan pemanfaatan analisis citra berbasis objek ini sangat efektif dari segi waktu dalam proses pemetaannya . Selain itu, hasil akurasinya juga sangat baik, seperti yang tertera pada Tabel 3 berikut ini:

Tabel 3. Akurasi keseluruhan (Overall Accuracy) hasil klasifikasi $R F$

\begin{tabular}{llll}
\hline Tahun & DKI. Jakarta & Semarang & Surabaya \\
\hline 2005 & - & - & - \\
2015 & $92,0 \%$ & $93,7 \%$ & $86,2 \%$ \\
\hline
\end{tabular}

Sumber: Hasil analisis menggunakan metode uji akurasi Error Matrix Based on TTA Mask

Pada penelitian ini perhitungan akurasi hanya dilakukan pada hasil klasifikasi citra tahun 2015, sedangkan untuk tahun 2005 tidak dilakukan uji akurasi karena peta permukiman tahun 2005 dihasilkan dari peta permukiman tahun 2015 dengan cara mengurangi batas permukiman atau menghapus poligon untuk permukiman yang belum terbangun. Hasil pemetaan permukiman perkotaan pada tiga kota metropolitan seperti pada Gambar 2 berikut ini.

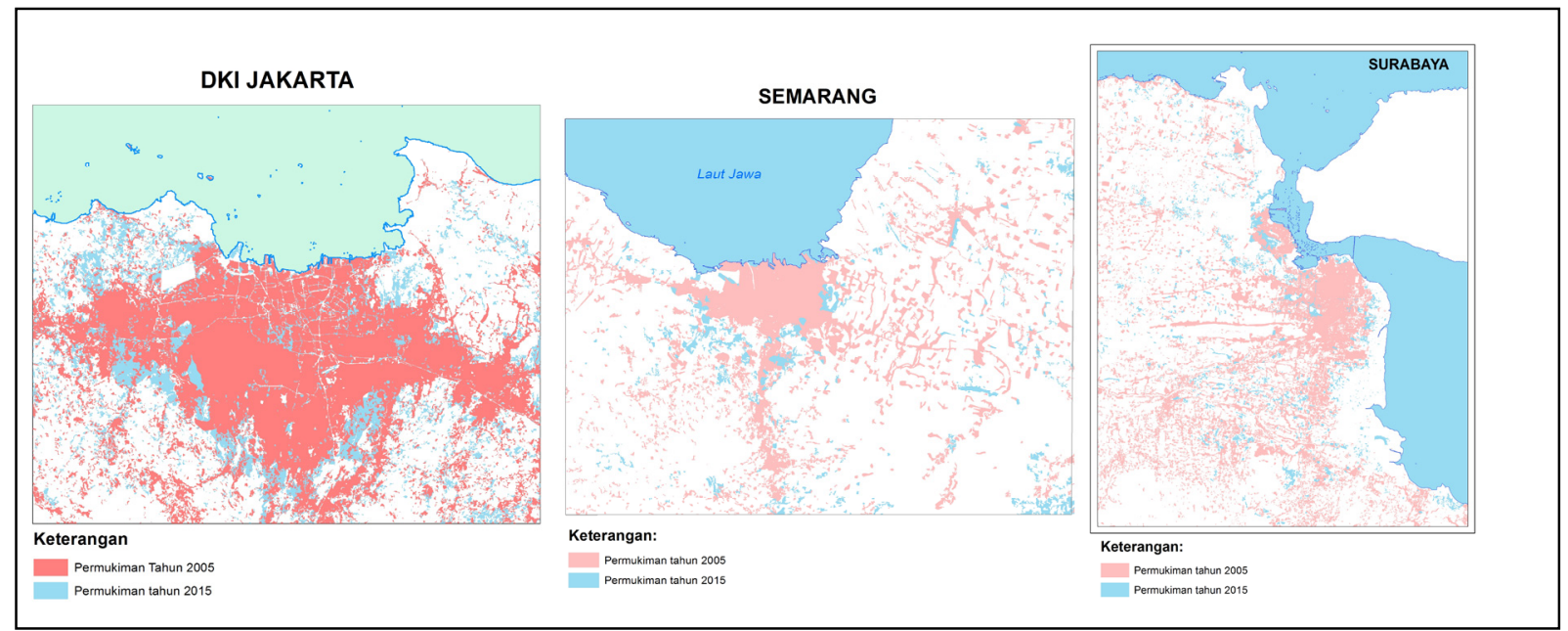

Gambar 2. Ekspansi perkotaan di tiga kota metropolitan dari tahun 2005 sampai dengan tahun 2015 (Sumber: Hasil analisis citra berbasis objek dengan klasifikasi RF, 2017) 


\section{Analisis Pola Spasiotemporal Ekspansi Perkotaan di tiga wilayah perkotaan metropolitan dari tahun 2005 sampai dengan tahun 2015}

Selama satu dekade terakhir, Jakarta, Semarang dan Surabaya semuanya telah mengalami urbanisasi yang pesat (Gambar 2) yang dapat dilihat dari perluasan lahan perkotaan secara terus menerus. Dari Gambar 2 dapat dilihat bahwa Jakarta mengalami perkembangan ke segala arah akan tetapi perkembangan yang paling pesat lebih mengarah ke arah Barat Laut (Kota Tangerang), Barat Daya (Kota Tangerang Selatan dan Kota Depok) dan Tenggara (Kabupaten Bogor). Untuk Kota Semarang perkembangan lebih mengarah ke Selatan (Kabupaten Semarang) dan Barat Daya (Gambar 2) dan Kota Surabaya perkembangan kota lebih mengarah ke Barat Laut (Kabupaten Gresik) dan Selatan (Kabupaten Sidoarjo).

Jakarta yang merupakan bagian dari Kawasan Jabodetabek mengalami ekspansi perkotaan yang paling besar yaitu seluas $557,53 \mathrm{~km}^{2}$ dalam 10 tahun terakhir atau mengalami kenaikan sebesar $55,753 \mathrm{~km}^{2}$ per tahun dengan tingkat pertumbuhan ekspansi perkotaan rata-rata pertahun adalah 3,47 persen. Hal ini tidak dapat dipungkiri karena DKI. Jakarta merupakan Ibu Kota Negara sekaligus pusat pemerintahan dan juga pusat bisnis di Indonesia. Menurut Hidajat (2013) Indeks Sprawl di wilayah pinggiran kota metropolitan Jakarta (seperti Kota Depok) pada tahun 2005-2010 sebesar 7,21. Ini menunjukkan pertumbuhan permukiman lebih dominan dibandingkan pertumbuhan penduduk. Pembangunan perumahan dengan skala besar sudah mulai merambah lahan-lahan hijau diikuti oleh penurunan jumlah anggota keluarga. Pertumbuhan yang sangat pesat ini menimbulkan wacana yang sudah lama muncul dan mulai hangat baru-baru ini, yaitu tentang kemungkinan dilakukannya pemindahan ibu kota pemerintahan, hal ini dalam upaya untuk lebih mengendalikan ekspansi perkotaan selain upaya pemerataan pembangunan di wilayah Negara Indonesia.

Kota Surabaya dengan Kawasan Gerbang Kerto Susilo menempati urutan selanjutnya dari wilayah penelitian ini yang pesat ekspansi perkotaannya. Selama kurun waktu 10 tahun terakhir terjadi ekspansi perkotaan seluas $171,85 \mathrm{~km}^{2}$ atau rata-rata pertahun meningkat sebesar $17,19 \mathrm{~km}^{2}$ dengan pertumbuhan rata-rata ekspansi sebesar 1,61 persen per tahunnya dalam lingkup wilayah penelitian ini. Dilihat dari penutup lahan yang ada di wilayah penelitian, maka sebagian besar perkotaan metropolitan ini masih merupakan kategori pedesaan yang didominasi oleh penutup lahan pertanian. Pada Gambar 2 memperlihatkan bahwa ekspansi perkotaan lebih terpusat di Kota Surabaya, sementara kota-kota disekitarnya terlihat cukup lambat perkembangannya. Kawasan ini lebih memadatkan permukiman di dalam dan di sekitar Kota Surabaya, hanya sebagian kecil permukiman yang berekspansi ke arah luar Kota Surabaya. Hal ini terjadi karena Kota Surabaya selain sebagai ibu kota provinsi juga sebagai pusat bisnis dan industri, sehingga memiliki sarana dan prasarana infrastruktur yang lengkap. Untuk mengatasi hal ini maka beberapa pusat pertumbuhan seperti kawasan industri perlu dikembangkan ke wilayah yang lain, misalnya pengembangan kawasan industri di wilayah Bangkalan dan Lamongan. Pembangunan Jembatan Suramadu dan Jalan Tol Surabaya-Mojokerto diharapkan juga akan lebih melancarkan transportasi antar wilayah di kawasan ini, sehingga wilayah yang alin akan lebih cepat berkembang.

Kota Semarang sebagai pusat dari metropolitan Kedungsepur adalah kota yang terkecil dari ketiga kota metropolitan dalam penelitian ini. Selama kurun waktu 10 tahun terakhir di kawasan ini mengalami perkembangan perkotaan sebesar $94,90 \mathrm{~km}^{2}$, dengan rata-rata per tahunnya mengalami perkembangan sebesar $9,49 \mathrm{~km}^{2}$, dan pertumbuhan rata-rata ekspansi perkotaan sekitar 1,9 persen per tahunnya, bahkan kecepatan pertumbuhannya melebihi Kota Surabaya (Kawasan Gerbang Kerto Susilo). Perkembangan Kota metropolitan Semarang (Kedungsepur) tidak sepesat seperti Jakarta, Surabaya, Bandung dan Medan. Hal ini dapat dilihat dari jumlah penduduknya dan kelengkapan fasilitas kotanya (Jones , 2002). Beberapa kecamatan yang ada di lingkup Kota Semarang juga masih didominasi oleh lahan pertanian dan perkebunan seperti Kecamatan Mijen, Gunung Pati dan Ngaliyan. Perkembangan yang paling pesat terjadi ke arah selatan, sepanjang jalan Semarang-Yogyakarta, mengarah ke Kabupaten Semarang. 
Tabel 3. Morfologi Ekspansi Perkotaan Tahun 2005-2015

\begin{tabular}{|c|c|c|c|c|c|c|}
\hline \multirow[t]{2}{*}{ Tahun } & \multicolumn{2}{|c|}{ DKI Jakarta } & \multicolumn{2}{|c|}{ Semarang } & \multicolumn{2}{|c|}{ Surabaya } \\
\hline & $\mathrm{A}_{\text {model }}\left(\mathrm{km}^{2}\right)$ & $\mathrm{P}_{\text {model }}(\%)$ & $\mathrm{A}_{\text {model }}\left(\mathrm{km}^{2}\right)$ & $\mathrm{P}_{\text {model }}(\%)$ & $\mathrm{A}_{\text {model }}\left(\mathrm{km}^{2}\right)$ & $\mathrm{P}_{\text {model }}(\%)$ \\
\hline Edge Expansion & 461,66 & 82,80 & 28,99 & 30,55 & 65,90 & 38,35 \\
\hline Infilling & 24,33 & 4,36 & 13,34 & 14,06 & 47,30 & 27,52 \\
\hline Outlying & 16,68 & 2,99 & 38,08 & 40,13 & 48,96 & 28,49 \\
\hline Stripping & 53,63 & 9,62 & 14,56 & 15,34 & 9,31 & 5,42 \\
\hline
\end{tabular}

Sumber: Hasil analisis

Pada Gambar 3 memperlihatkan pola spasiotemporal ekspansi perkotaan dari tahun 2005 sampai dengan tahun 2015. Pola spasiotemporal ekspansi perkotaan untuk DKI. Jakarta (Jabodetabek) dan Surabaya (Gerbang Kerto Susilo) didominasi oleh tipe perkembangan tepi (Edge-expansion), sementara Kota Semarang (Kedungsepur) didominasi oleh tipe meloncat (leapfrog/ outlying) (Tabel 3.). Perbedaan pola ini dipengaruhi oleh ukuran kota, kawasan perkotaan metropolitan yang memiliki ukuran kota yang besar cenderung memiliki tipe Edge-expansion atau Infilling tapi tidak leapfrogging/ outlying, atau dapat dikatakan bahwa, tipe leapfrogging/outlying akan menurun seiring dengan meningkatnya ukuran kota. Dalam kata lain, kota yang berukuran kecil lebih cenderung berkembang dalam model lompatan (leapfrogging/outlying) (Yu, 2017).
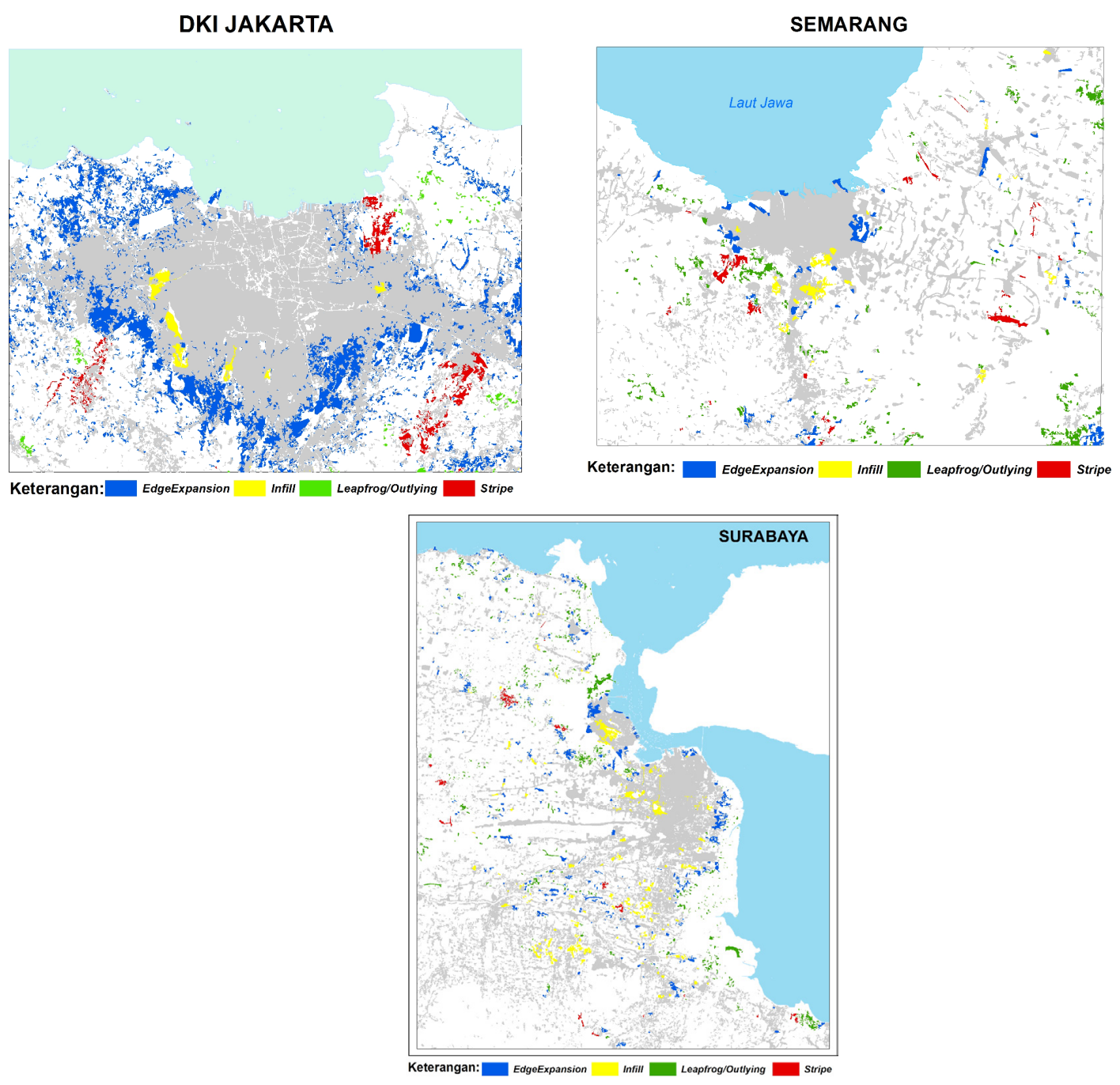

Gambar 3. Tipe Ekspansi Perkotaan Pada Tiga Kota Metropolitan Daerah Penelitian (Sumber: Hasil analisis kuantifikasi tipolgi ekspansi perkotaan, 2017) 
Dari uraian sebelumnya Jakarta mengalami ekspansi perkotaan yang relatif cepat, hal ini juga mempengaruhi tipe ekspansi perkotaan. Kecepatan ekspansi yang tinggi cenderung membentuk tipe ekspansi berupa perluasan tepi (Edge-expansion) (Yu, 2017). Ini terjadi karena pusat kota sangat mempengaruhi ekspansi kota-kota di sekitarnya, sehingga perkembangan permukiman baru akan cenderung mendekati pusat-pusat tersebut. Hal ini selaras dengan penelitian yang dilakukan oleh Ju, et al (2016) bahwa ukuran kota yang lebih besar akan memiliki kecepatan ekspansi perkotaan yang relatif lebih tinggi dan perluasan lahan akan cenderung terjadi di dekat-dekat lahan terbangun sebelumnya.

Pada kasus Kota Semarang yang memiliki ukuran yang lebih kecil, akan lebih cenderung berkembang dalam tipe lompatan (leapfrogging/outlying). Ketika sebuah kota berada dalam tahap awal terbentuk, banyak permukiman baru dibangun, sehingga mengakibatkan banyak jejak lompatan. Setelah kota berkembang, kota akan mungkin mengalami ekspansi yang cepat, dan hal ini biasanya terkait dengan peningkatan ekspansi ke arah luar yang lebih cepat daripada patch leapfrogging/ outlying yang telah dibuat sebelumnya. Akhirnya patch yang tumbuh ini bergabung dengan patch di sekitarnya, dan menjadi patch dengan tipe perluasan tepi (Edge-expansion) yang lebih besar. Akibatnya, setelah proses ekspansi ini, ukuran kota sebagian besar akan berkorelasi negatif dengan tipe lompatan (leapfrogging/outlying), dan kecepatan ekspansi perkotaan relatif memiliki korelasi yang positif pada tipe perluasan tepi (Edge-expansion) (Yu, 2017). Pada tahap awal ekspansi perkotaan, tipe lompatan (leapfrog/outlying) umumnya merupakan tipe yang dominan, sedangkan model ekspansi tepi (Edge-expansion) mendominasi pada tahap ekspansi yang cepat, dan infilling menjadi mode ekspansi utama pada tahap stabil (Yu, 2017).

\section{KESIMPULAN DAN SARAN}

\section{Kesimpulan}

Data Landsat ETM+ dan OLI yang memiliki resolusi spasial menengah dapat dimanfaatkan untuk memetakan pola ekspansi perkotaan melalui metode klasifikasi berbasis objek dengan algoritma Random Forest dengan akurasi yang baik dan cukup efektif dari segi waktu pengerjaannya. Hasil penelitian menunjukkan bahwa besarnya ekspansi perkotaan, morfologi ekspansi perkotaan dan tipe ekspansi perkotaan sangat bervariasi antara kota-kota besar. Dalam penelitian ini menemukan bahwa ketiga metropolitan perkotaan pada daerah penelitian mengalami perkembangan yang cepat dan masif, serta memiliki pola spasiotemporal yang sangat bervariasi. Kota-kota yang lebih besar cenderung memiliki lahan-lahan yang baru dikembangkan dan berekspansi pada tingkat yang relatif lebih cepat. Ukuran kota mempengaruhi pola ekspansi perkotaan, diikuti oleh tingkat kecepatan ekspansi. Ukuran kota yang lebih besar dengan ekspansi yang relatif cepat lebih cenderung mengalami model perluasan tepi (Edge-expansion), sementara kota-kota yang lebih kecil cenderung berkembang dengan model lompatan (leapfrogging).

\section{Saran}

1. Sebaiknya menggunakan citra penginderaan jauh dengan selang perekaman 5 tahun, mengingat perkembangan kota yang relative cepat.

2. Perlu dipilih kualitas perekaman citra yang baik untuk meminimalisir kesalahan dalam proses pemisahan antara bangunan dan tanah kering pada saat klasifikasi OBIA.

\section{UCAPAN TERIMA KASIH}

Ucapan terimakasi kepada Departemen Teknologi Kebumian, Program Studi Diploma III Penginderaan Jauh dan Sistem Informasi Geografi Sekolah Vokasi UGM atas kesempatan dan hibah yang telah diberikan sehingga penulis dapat menyelesaikan penelitian ini 


\section{DAFTAR PUSTAKA}

\section{Pustaka jurnal penelitian}

A.A. Belal', F.S. Moghanm, (2011) Detecting urban growth using remote sensing and GIS techniques in Al Gharbiya governorate, Egypt. The Egyptian Journal of Remote Sensing and Space Science. 14: 73-79

Angelica I. STAN, (2013). Morphological Patterns of Urban Sprawl Territories. Urbanism. Arhitectură. Construcţii • Vol. $4 \cdot$ Nr. 4

Breiman, L., (2001). Random forest. Mach. Learning 45: 5-32

Cutler, David Richard, Thomas C. Edward, Karen, H Beard, Joshua J. Lawler, (2007). Random Forest for Classification in Ecology, Ecology 88(11): 2783-92

Díaz-Uriarte and Sara Alvarez de Andrés (2006). Gene selection and classification of microarray data using random forest. BMC Bioinformatics 7/3: 1-13

Duro, D.C., Franklin, S.E., Dube, M.G.,(2012). A comparison of pixel-based and object-based image analysis with selected machine learning algorithms for the classification of agricultural landscapes using SPOT-5 HRG imagery. Remote Sens. Environ. 118: 259-272.

Forman, Richard T., (1995), Land Mosaics: the ecology of landscapes and regions: Land Mosaics: the ecology of landscapes and regions. Cambridge University Press, Cambridge.

Genuera, Robin, Jean-Michel Poggi, Christine Tuleau-Malotc. (2010). Variable selection using Random Forests. Pattern Recognition Letters 31: 142225-2236

Guo, L., Chehata, N., Mallet, C., Boukir, S., (2011). Relevance of airborne lidar and multispectral image data for urban scene classification using Random Forests. ISPRS International Journal of Photogrammetry and Remote Sensing 66: 56-66

Hoffhine Wilson, E., Hurd, J.D., Civco, D.L., Prisloe, M.P., Arnold, C., 2003. Development of a geospatial model to quantify, describe and map urban growth. Remote Sens. Environ 86 (3): $275-285$

Huang, J., Lu, X., Sellers, J., 2007. A global comaparative analysis of urban foirm; applying spatial metrics and remote sensing . Landscape Urban Plan 82(4) 184-197

Janthy Trilusianthy Hidajat, Santun R.P Sitorus, Ernan Rustiadi dan Machfud (2013) Dinamika Pertumbuhan dan Status Keberlanjutan Kawasan Permukiman di Pinggiran Kota Wilayah Metropolitan Jakarta. Globe Volume 15 No. 1Juni 2013 : 93 - 100

Karen C. Seto, Michail Fragkias, Burak Güneralp, Michael K. Reilly. (2011). A Meta-Analysis of Global Urban Land Expansion. PLoS ONE, 6, e23777. [online] http://dx.doi.org/10.1371/journal.pone.0023777 (Published: August 18, 2011) (diakses : 9 Maret 2017)

Lambin, E.F., 1996. Change detection at multiple scales: seasonal and annual variations in landscape variables. Photogrammetric Engineering and Remote Sensing, 62:931-938

Lei Ma, Tengyu Fu, Thomas Blaschke, Manchun Li, Dirk Tiede , Zhenjin Zhou , Xiaoxue Ma and Deliang Chen, (2017), Evaluation of Feature Selection Methods for Object-Based Land Cover Mapping of Unmanned Aerial Vehicle Imagery, ISPRS Int. J. Geo-Inf., 6: 51; doi:10.3390/ijgi6020051 www.mdpi.com/journal/ijgi

Lichtenegger, J., 1992. ERS-1: land use mapping and crop monitoring: a first close look to SAR data. Earth Observation Quarterly, (May-June):37-38.

Lo, C.P., 1981. Land use mapping of Hong Kong from landsat images: an evaluation. Int. J. Rem. Sens. 2 (3), 231-251 
Luck M. and Wu J. 2002. A gradient analysis of urban landscape pattern: A case study from the Phoenix Metropolitan region of USA. Landscape Ecology 17: 327-329

Ma, L.; Cheng, L.; Li, M.; Liu, Y.; Ma, X. (2015) Training set size, scale, and features in geographic object-based image analysis of very high resolution unmanned aerial vehicle imagery. ISPRS International Journal of Photogrammetry and Remote Sensing, 102: 14-27

Muchoney, D.M., Haack, B.N., 1994. Change detection for monitoring forest defoliation. Photogrammetric Engineering and Remote Sensing, 60:1243-1314

Mukherjee, S., 1987. Landuse maps for conservation of ecosystems. Geogr. Rev. Ind. 3, 23-28

Puissant, A.; Rougier, S.; Stumpf, A. (2014). Object-oriented mapping of urban trees using random forest classifiers. Int. J. Appl. Earth Obs. Geoinf., 26: 235-245.

Quarmby, N.A., Cushine, J.L., 1989. Monitoring urban land cover changes at the urban fringe from SPOT HRV imagery in South East England. Int. J. Rem. Sens. 10 (6), 231-251.

Sailer, C.T., Eason, E.L.E., Brickey, J.L., 1997. Operational multispectral information extraction: the DLPO image interpretation program. Photogrammetric Engineering and Remote Sensing, 63:129-136

Schneider, A.; Mertes, C.M. (2014). Expansion and growth in Chinese cities, 1978-2010. Environ mental Research Letters, 9: 69-75.

Sierra, P. Pons, X., Sauri., D., 2003. Post-classification change detection with data from different sensors; some accuracy considerations. Int. J. Remote Sensing 24 (16), 3311-1140

Stumpf, A.; Kerle, N. (2011) Object-oriented mapping of landslides using random forests. Remote Sens. Environ., 115: 2564-2577

Tateishi, R., Kajiwara, K., 1991. Global Lands Cover Monitoring by NOAA NDVI Data. Proceeding of International Workshop of Environmental Monitoring from Space. Taejon, Korea, p.37-48.

Wenjia Wu, Shuqing Zhao, Chao Zhu, Jinliang Jiang. (2015). A comparative study of urban expansion in Beijing, Tianjin and Shijiazhuang over the past three decades. Landscape and Urban Planning 134 : 93-106

Wenjuan Yu, Weiqi Zhou, Yuguo Qian, Jingli Yan. (2016). A new approach for land cover classification and change analysis: Integrating backdating and an object-based method. Remote Sensing of Environment 177: 37-47 [online] www.elsevier.com/locate/rse (diakses: 1 Maret 2017)

Wenjuan Yu and Weiqi Zhou.(2017). The Spatiotemporal Pattern of Urban Expansion in China: A Comparison Study of Three Urban Megaregions. Remote Sens. 9: 45

Wu, J.; Jenerette, G.D.; Buyantuyev, A.; Redman, C.L (2011) Quantifying spatiotemporal patterns of urbanization: The case of the two fastest growing metropolitan regions in the United States. Ecol. Complex 8: 1-8.

Xian, G. Crane, M., 2005. Assesments of urban growth in the Tampa Bay watershed using remote sensing data. Remote Sensing Env. 97(2)203-215

Xu, C.; Liu, M.S.; Zhang, C.; An, S.Q.; Yu, W.; Chen, J.M. (2007). The spatiotemporal dynamics of rapid urban growth in the Nanjing metropolitan region of china. Landsc. Ecol., 22: 925-937.

Van der Geer, J., Hanraads, J. A. J., \& Lupton, R. A. (2010). The art of writing a scientific article. Journal of Scientific Communications, 163: 51 - 59. 


\section{Pustaka buku}

BPS Kota Surabaya, Kota Surabaya Dalam Angka 2015

BPS Kota Semarang, Kota Semarang Dalam Angka 2016

BPS Statistik DKI. Jakarta. Statistik Daerah Provinsi DKI Jakarta 2015

Elena Besussi, Nancy Chin, Michael Batty, and Paul Longley (Chapter 2). T. Rashed and C. Jürgens (eds.), (2010). Remote Sensing of Urban and Suburban Areas, Remote Sensing and Digital Image Processing, Springer Science+Business Media B.V

Forman, Richard T., (1995), Land Mosaics: the ecology of landscapes and regions: Land Mosaics: the ecology of landscapes and regions. Cambridge University Press, Cambridge.

I Made Parsa dan Tatik Kartika (2015). Teknik Segmentasi dan Klasifikasi Berjenjang Untuk Pemetaan Lahan awah Menggunakan Citra SPOT-6 (Studi Kasus Kabupaten Maros, Sulawesi Selatan). Pemmanfataan Citra Penginderaan Jauh untuk Sumberdaya Wilayah Darat. Bogor; CRESTPENT Press

\section{Pustaka Web}

Khila Dahar (2015). Urban growth forms or types. http://www.arcgis.com/home/ item.html?id=325cb9c2b45a4e87b544f10ef78f51b0, diakses tanggal 13 Juli 2017

\section{Pustaka Prosiding}

Indrawati, Like, Sudaryatno (2016). Pemetaan Berorientasi Objek Untuk Ekstraksi Bangunan danVegetasi di Area Perkotaan Menggunakan Klasifikasi Random Forest Pada Citra Pleides 1B. Prosiding Seminar Nasional Teknologi Terapan Tahun 2016. Sekolah Vokasi UGM. 